\title{
The Influence of Inclusive Policy by The General Election Commission to The Participation Rate of Voters with Disabilities in The 2017 Simultaneous Regional Head Elections in Indonesia
}

\author{
Nadya Kharima \\ Social Welfare Study Program \\ Syarif Hidayatullah State Islamic University \\ Jakarta, Indonesia \\ nadya.kharima@uinjkt.ac.id
}

\begin{abstract}
Simultaneous Regional Head Elections (Pilkada) had been contested on February 15, 2017. The event of democracy party in $\mathbf{1 0 1}$ districts in Indonesia has a new history that is the increase of the participation rate of people with disabilities up to 257.7 percent. The high participation rate of voters with disabilities becomes one benchmark of inclusive society. Many factors can lead to high participation rate of voters with disabilities; one of them is the creation of a friendly election for people with disabilities (accessible). The General Election Commission (KPU) as a state institution with the task of organizing elections at both central and regional level is required to make policies that are friendly to voters with disabilities. This descriptive qualitative research aims to see the influence of KPU policy on the participation rate of voters with disabilities and see whether the policy contribute to the success of increasing participation of voters with disabilities in the 2017 Simultaneous Regional Head Elections in Indonesia. Thus, hopefully in the future, the government will understand the importance of policy function in encouraging inclusive society towards people with disabilities.
\end{abstract}

Key words: inclusive policy, 2017 elections, KPU, voters with disabilities

\section{INTRODUCTION}

Elections and Voters with Disabilities are a continuous topic and always an interesting discourse discussed because it is always considered as one of the problems that exists in the election process in Indonesia. The election is a means of participation for all people of Indonesia, including people with disabilities. Unfortunately, in every election held, people with disabilities considered to receive inadequate attention.

Whereas it is clearly stated in [1] that the Election, viewed from the perspective of Human Rights (HAM), is the implementation of the basic rights and the future of common life in a society. People with disabilities are part of the people who have the same rights to vote in the election or the so-called voters.

In addition to the fact that Indonesia has ratified the International Covenant on Civil and Political Rights (ICCPR), the United Nations international treaty of 1966.
The ICCPR took effect in 1976 and has been ratified by 141 countries. The substance set forth in this agreement is the respect for human rights which obliges the participating states to transform into national law. Among the ICCPR contents relating to the rights of people with disabilities is Article 25 which reads "Every citizen shall have the right and opportunity, without any distinction to take part in the conduct of public affairs, directly or through freely chosen representatives; to vote and to be elected at genuine periodic elections which shall be by universal and equal suffrage and shall be held by secret ballot, guaranteeing the free expression of the will of the electors; and to have access to public service in his country on general terms of equality" [2]

Then in 2016, the Government has adopted a new Law on People with Disabilities in which the political rights of people with disabilities in Indonesia are actually protected in Article 13. The Article clearly states that "The Political Rights of People with Disabilities is to vote and to be elected in public positions; to channel both written and oral political aspirations; to elect political parties and/or individuals participating in the election; to form, to become members and/or administrators of community organizations and/or political parties; to establish and join People with Disabilities organizations and to represent the people at the local, national and international levels; to participate actively in the electoral system at all stages and/or in parts of its organizers; to gain accessibility to facilities and infrastructure for the general elections, governors, regents/mayors, and village head elections or other names and; to gain political education".

Now, the 2017 Simultaneous Regional Head Election held in 101 districts has recorded a new history of election in Indonesia where the participation rate of people with disabilities increased significantly compared to that in the previous elections. The elections held on February 15, 2017 increased by an average of 257 percent compared to the previous elections.

This emerging history can be a fresh air over the complexity of problems that arise against voters with 
disabilities in the election. There are many factors that lead to high participation rate of voters with disabilities, one of which is the creation of elections that are friendly to voters with disabilities or accessible. So far, many facts have shown that elections have not been able to be friendly to people with disabilities, such as unreadable voting papers for blind people, voting locations (TPS) that unreachable by wheelchair users, and many more issues that arise.

The General Election Commission (KPU) as a state institution with the task of organizing elections at both central and regional level plays that important role in creating accessible elections. Since the 2014 election, KPU has begun to improve its capacity in providing service of suffrage for people with disabilities, such as making pro-policy for voters with disabilities, because of the high expectation that the policies made by KPU can create accessible elections in Indonesia.

Although the election is a very important momentum, it is still often raises the issue for people with disabilities. Therefore, an understanding of election organizers is needed to facilitate the special needs of people with disabilities in order to participate actively in the General Elections [3]

Looking at the phenomenon, the author feels important to see whether there is the influence of KPU's policies as the election organizers to the participation rate of voters with disabilities in the 2017 simultaneous regional elections in Indonesia. Thus, this research can become a reference suggesting the importance of policy function in encouraging inclusive society toward people with disabilities.

\section{METHODS}

This paper aims to see the influence of KPU policies on participation rate of voters with disabilities, and to see whether the policy can be one key success of increased participation rate of voters with disability in the 2017 simultaneous regional head elections in Indonesia. Thus, this study uses a qualitative descriptive approach that aims to provide a precise picture of the relationship above by exploring and understanding the meaning of social problems.

In addition to aiming to carefully describe the characteristics of a symptom or a problem studied, a descriptive research also focuses on the basic question of "how" by trying to get and deliver the facts clearly, thoroughly and completely without many unimportant details as that in an exploratory research. The central point of the descriptive research [4] is to suggest the features of something that may be done more than that, but can not be less than that and are still referred to as a description. The better the description, the greater the chance that the parts obtained from the description will be useful in building the next theory.

\section{DISCUSSIONS}

Based on KPU Information System data, there are 50,108 voters with disabilities registered in the permanent voters list (DPT). In fact, more than 129,000 voters with disabilities come to vote. The average participation rate of voters with disabilities are 205 percent at the provincial level, 99 percent at the city level, and 296 percent at the regent level. The details are DKI Jakarta Province with 99.7 percent, Aceh Province with 968.2 percent, Bangka Belitung Province with 107.6 percent, Banten Province with 22.7 percent, Gorontalo Province with 81 percent, West Sulawesi with 61.3 percent and West Papua Province with 97.7 percent [5].

The following is an example of comparison of voters with disabilities data in the 2012 and 2017 elections of DKI Jakarta based on the author's summary obtained from Agenda:

TABLE I

\begin{tabular}{|c|c|c|c|}
\hline \multirow{2}{*}{ No } & \multirow{2}{*}{$\begin{array}{c}\text { Type of } \\
\text { Disabilities }\end{array}$} & \multicolumn{2}{|c|}{$\begin{array}{c}\text { Number of Voters with } \\
\text { Disabilities }\end{array}$} \\
\hline & & $\begin{array}{c}2012 \\
\text { Election }\end{array}$ & $\begin{array}{c}2017 \\
\text { Election }\end{array}$ \\
\hline 1 & $\begin{array}{c}\text { Vision Loss } \\
\text { and } \\
\text { Blindness }\end{array}$ & 60 & 587 \\
\hline 2 & $\begin{array}{l}\text { Physical } \\
\text { Disability }\end{array}$ & 65 & 1,509 \\
\hline 3 & $\begin{array}{l}\text { Hearing } \\
\text { Loss and } \\
\text { Deafness }\end{array}$ & 32 & 673 \\
\hline 4 & $\begin{array}{c}\text { Intellectual } \\
\text { Disability }\end{array}$ & 10 & 1,378 \\
\hline \multicolumn{2}{|c|}{ Total Voters } & 167 & 4,147 \\
\hline
\end{tabular}

From the data above, the increase in the number of voters with disabilities is quite large for DKI Jakarta alone. In the 2012 General Election of DKI Jakarta, there is no accurate information from the election organizer (KPU) related to voter data coming from people with disabilities. Please note that at the time of voter registration, the DKI Jakarta General Election Commission includes data of voters with disabilities, but at the time of election, the data is lost or not found in the data of Voters in each TPS in DKI Jakarta.

Whereas in 2017 , in contrast to previous elections, KPU has created permanent voters list (DPT) stating voters with disabilities.

Since the 2014 election, KPU has attempted to make changes to the regulatory system, where the policies made by KPU are not directly validated, and then made into a basic reference. In making policy, KPU also conducts consultation with commission II, public test and meetings with PPUA Penca to discuss policies included in KPU Regulation, so that enter into the phase of need development of change, stabilization of relation change, and clarification phase.

This is as revealed by KPU Commissioner, Ferry Kurnia Rizkiansyah:

"Yes, we are sharing with PPUA Penca, so our PKPU making process is very open, there is a public test that we do. So, besides consulting with government and DPR in the forums, we also have a public test". 
This is in line with the flow of policy-making process steps based on [6], where prior to the determination of the policy, needs assessment and objectivity specification are required prior to the implementation, so do continuous revision or evaluation until it can be well implemented.

In fact, KPU involves people with disabilities organization to go down to the braille manufacturing factory to measure the thickness of the braille templates for ballot papers. Still according to Ferry, even for those braille templates, they (people with disabilities) participate in quality control of the making process, worrying that the thickness of the ballot does not meet the requirement which make it unreadable.

Not only that, KPU finally incorporated its policy which was perceived as lacking in the guidebook of the Voters Committee (KPPS) for the policy to be implemented properly by KPPS as the executor. The KPPS Handbook has detailed information on accessible elections for people with disabilities, ranging from notice of braille templates for voters with disabilities and C3 form filling for companions. Here, stage of alternative assessment of the path, stage of will transformation, and stage of generalization are implemented.

However, in the implementation of the 2014 election, KPU seems to have limited time so that the policy made can not be fully conveyed during the election. The distance between the policy maker and the policy implementer is too far. In this connection, Pressman and Wildavsky warn that the policies of causality that depend on a very long chain will be easy to experience adherence [7]

In the 2017 Election, although still considered to have problems related to voters with disabilities data that has not been accurate, KPU has made several new policies. Among them is asking KPPS as the executor level to be active in conducting friendly elections for voters with disabilities. One of them is to ask KPPS at each voting place (TPS) to pick up and escort the voters with disabilities if there are difficulties to come to voting places during voting day [6].

Besides, the excellence of KPU's policy in the 2017 election lays on the production of KPPS Handbook that is much better than that in the previous elections. KPU puts it in separated chapter in Chapter V: Disability-Friendly Services in Voting. In the chapter, the KPU creates sufficiently detailed elections that are friendly for voters with disabilities, even in the book there are ways of KPPS in serving voters with blindness, deafness, intellectual disability, and psychosocial disability [8, p. 32-34]

Although the policies for voters with disabilities has previously described clearly, here the author tries to compare the policies that have been made by KPU in the 2009 General Election, the 2014 General Election, and the 2017 Regional Elections in general, so it appears that the policy has actually improved compared to the previous elections.
TABLE II

Compare the policies that have been made by KPU in the 2009 General Election, the 2014 General Election, and the 2017 Regional Elections in general

\begin{tabular}{|c|c|c|}
\hline \multicolumn{3}{|c|}{ INCLUSIVE POLICY DONE BY KPU } \\
\hline $\begin{array}{l}\text { THE } 2009 \text { GENERAL } \\
\text { ELECTION }\end{array}$ & $\begin{array}{c}\text { THE } 2014 \\
\text { GENERAL } \\
\text { ELECTION }\end{array}$ & $\begin{array}{c}\text { THE } 2017 \\
\text { REGIONAL } \\
\text { ELECTION }\end{array}$ \\
\hline $\begin{array}{l}\text { Guidebook/Technical } \\
\text { Guidance for PPK/PPS } \\
\text { officers made by KPU do } \\
\text { not contain } \\
\text { information/materials on } \\
\text { the importance of } \\
\text { accessible election for } \\
\text { people with disabilities. } \\
\text { KPU does not involve } \\
\text { organizations/people with } \\
\text { disabilities in designing } \\
\text { aids for disabled voters. } \\
\text { The use of tick marks that } \\
\text { make it difficult for people } \\
\text { with vision loss and } \\
\text { blindness because the tick } \\
\text { marks can be perceived } \\
\text { many things. }\end{array}$ & $\begin{array}{l}\text { KPPS Handbook } \\
\text { has detailed } \\
\text { information on } \\
\text { accessible } \\
\text { elections for } \\
\text { people with } \\
\text { disabilities, } \\
\text { ranging from } \\
\text { notice of braille } \\
\text { templates for } \\
\text { voters with } \\
\text { blindness, and C3 } \\
\text { form filling for } \\
\text { companions. } \\
\text { KPU involves } \\
\text { organizations of } \\
\text { people with } \\
\text { disabilities or } \\
\text { PPUA Penca in } \\
\text { their policies and } \\
\text { even asks the } \\
\text { people to go to a } \\
\text { braille } \\
\text { manufacturing } \\
\text { factory to measure } \\
\text { the thickness of the } \\
\text { braille template for } \\
\text { ballot papers. } \\
\text { The use of } \\
\text { perforation marks } \\
\text { is considered } \\
\text { easier for people } \\
\text { with disabilities } \\
\text { because it can be } \\
\text { done alone without } \\
\text { the help of a } \\
\text { companion. } \\
\text { Lack of } \\
\text { communication } \\
\text { between policy } \\
\text { makers and policy } \\
\text { implementers. }\end{array}$ & $\begin{array}{l}\text { In KPPS } \\
\text { Handbook, KPU } \\
\text { includes a } \\
\text { special Chapter } \\
\text { for people with } \\
\text { disabilities: } \\
\text { CHAPTER V } \\
\text { Disability- } \\
\text { Friendly } \\
\text { Services In } \\
\text { Voting. } \\
\text { KPU does not } \\
\text { only involve, but } \\
\text { also currently } \\
\text { ask for active } \\
\text { role of people } \\
\text { with disabilities } \\
\text { to participate in } \\
\text { the } 2017 \\
\text { elections. This is } \\
\text { done by } \\
\text { requesting the } \\
\text { KPPS to re- } \\
\text { collect data of } \\
\text { voters with } \\
\text { disabilities. } \\
\text { KPPS is asked } \\
\text { to participate in } \\
\text { creating the } \\
\text { friendly- } \\
\text { disability } \\
\text { elections for } \\
\text { voters with } \\
\text { disabilities. } \\
\text { (This is } \\
\text { important } \\
\text { because the } \\
\text { policy maker } \\
\text { has to } \\
\text { communicate up } \\
\text { to the level of } \\
\text { executor) }\end{array}$ \\
\hline
\end{tabular}

\section{CONCLUSION}

Based on the above analysis, it can be concluded that the policy made should be continuously studied and regularly reviewed in order to produce the policy that can really support the realization of an inclusive policy.

In addition, how a policy can be properly implemented matters, whether the policy is already properly implemented or not must be a serious concern of policymakers. Because learning from general elections, the far distance between policymakers (KPU) and policy implementers (KPPS) may cause vulnerable structure in terms of communication and bureaucracy. KPPS Handbook can be one of the solutions for policy makers to anticipate the existence of such vulnerabilities.

Moreover, the most important thing is that policymakers should always involve people with disabilities in making 
inclusive policies, because after all the people with disabilities themselves that will ultimately feel the good and bad of the policy. Therefore, it is fair if the increase in the number of voters with disabilities is one result of the inclusive policies made by KPU because the disabled voters can perceive how the policy is implemented properly.

\section{REFERENCES}

[1] H. G. Abdul and Nusantara, Pemilu dalam Perspektif HAM, dalam Mendemokratiskan Pemilu. Jakarta: ELSAM, 1996.

[2] Agenda, "Laporan Agenda Asia : Kegiatan Pemantauan Aksesibilitas dan Pemilu bagi Penyandang Disabilitas," AGENDA, Jakarta, 2013

[3] P. PPUA, Buku Panduan Akses Pemilu, Jaminan Partisipasi Politik bagi Penyandang Disabilitas. Jakarta: PPUA PENCA, 2011.

[4] U. Silalahi, Metode Penelitian Sosial, 2nd ed. Bandung: Refika Aditama, 2010.

[5] F. Kurnia Rizkiansyah, Potret Partisipasi Pilkada Tahun 2017. Jakarta: KPU, 2017.

[6] D. Prastiwi, "KPU : Tingkat Partisipasi Pemilih Disabilitas Tinggi di Pilkada."

[7] S. A. Wahab, Analisis Kebijakan : Dari Formulasi ke Implementasi Kebijaksanaan negara. Jakarta: Bumi Aksara, 2004.

[8] Buku Panduan KPPS. Jakarta: KPU, 2017. 